University of Rhode Island

DigitalCommons@URI

The Rhode Island Current Conditions Index

Economics

$9-2016$

\title{
Rhode Island Current Conditions Index - September 2016
}

Leonard Lardaro

University of Rhode Island, lardaro@uri.edu

Follow this and additional works at: https://digitalcommons.uri.edu/ricci

Part of the Econometrics Commons

Terms of Use

All rights reserved under copyright.

\section{Recommended Citation}

Lardaro, Leonard, "Rhode Island Current Conditions Index -- September 2016" (2016). The Rhode Island Current Conditions Index. Paper 153.

https://digitalcommons.uri.edu/ricci/153

This Article is brought to you for free and open access by the Economics at DigitalCommons@URI. It has been accepted for inclusion in The Rhode Island Current Conditions Index by an authorized administrator of DigitalCommons@URI.For more information, please contact digitalcommons-group@uri.edu. 


\title{
CURRENT CONDITIONS
}

\section{LEONARD LARDARO, URI}

\author{
Available Online: http:/ / www .Ilardaro.com/ current.htm \\ Blog: http:/ / rieconomy.blogspot.com
} Twitter: @ladardo

VOL XXIMT

NUMBER 10

SEP 2016
Now that the third quarter is "in the books," it is safe to characterize Rhode Island's performance during that quarter as "the un-second quarter," a vivid illustration of how much of a difference a quarter can make. Rhode Island's second quarter performance was, to put it kindly, a major disappointment. It did serve one important purpose however: it was a vivid reminder that when the US economy hiccups, Rhode Island's economy wil still falter. In a better run state, elected officials would have instituted numerous measures, mostly structural changes, from the onset of the Great Recession and continuing without end Such efforts would have reinvented our state's economy, insulating us more completely from national economic weakness But this is Rhode Island. We only began any meaningful reform efforts a year or two ago. Sadly, as the second quarter shows, we have a very long way to go. Fortunately for our elected officials, Rhode Island voters are extremely faithful. Their reaction to all of this, as inferred from the results of the recent election and virtually all since 1991, can be compared to the pledge night scene in the movie Animal House: "Thank you sir, may I have another." The fault for Rhode Island's endogenous mediocrity at this point lies entirely with its voters who demand virtually nothing and traditionally are all too willing to settle for even less!

During the third quarter, Rhode Island essentially erased the weakness it experienced during the prior quarter. The Current Conditions Index for September sustained at its August value of

\begin{tabular}{|l|r|l|}
\hline \multicolumn{3}{|c|}{ CCI Indicators - \% Change } \\
\hline Government Employment & 0.5 & Y \\
\hline US Consumer Sentiment & 4.8 & Y \\
\hline Single-Unit Permits & -6.9 & \\
\hline Retail Sales & 1.5 & Y \\
\hline Employment Services Jobs & 0.1 & Y \\
\hline Priv. Serv-Prod Employment & 1.2 & Y \\
\hline Total Manufacturing Hours & -0.2 & \\
\hline Manufacturing Wage & 6.8 & Y \\
\hline Labor Force & 0.7 & Y \\
\hline Benefit Exhaustions & -10.8 & Y \\
\hline New Claims & -19.0 & Y \\
\hline Unemployment Rate (change) & 0.0 & \\
\hline \multicolumn{2}{|c|}{ Y I Improved Value } \\
\hline
\end{tabular}

75, tied for its highest yet this year, marking what for Rhode Island is a momentous event: we have now matched or exceeded our year-earlier $\mathrm{CCl}$ value for three consecutive months (all of which were in Q3, coincidentally). While the pace of economic activity here did accelerate during the third quarter, we find ourselves essentially where we left off at the end of the first quarter. This is readily apparent when one considers the magnitudes of changes in this month's CCl indicators. Several, most notably Employment Service Jobs, which includes temporary employment and is a prerequisite to employment growth, barely changed $(+0.1 \%)$. The question now is whether it will revert to its prior downtrend as this year ends.
For September, nine of the $\mathrm{CCl}$ 's twelve indicators improved. Two of the indicators that have been acting atypically (for us at least) did so again this month. Government Employment, rose for only the third time since August of last year $(+0.5 \%)$. On a monthly basis, our Labor Force rose for the fourth consecutive time, indicating that some unemployed, by resuming job search, are once again reflected in our Unemployment Rate. Speaking of our jobless rate, it remained unchanged over both the prior month and compared to a year ago. For the first time in quite a while, our Unemployment Rate failed to improve. The good news for Rhode Island, though, is that our Labor Force has now improved on a yearly basis for two consecutive months! The last time that occurred was in the second quarter of 2014.

New Claims, the most timely measure of layoffs, fell sharply in September $(-19 \%)$, its second improvement in the last six months. US Consumer Sentiment rose by 4.8 percent, only its second improvement this year. Single-Unit Permits fell in September $(-6.9 \%)$, but had a very difficult comp a year ago. Employment Service Jobs, as noted earlier, barely managed to improve. Total Manufacturing Hours, a proxy for manufacturing output, fell by 0.2 percent in September, capping a disappointing performance for Rhode Island's goods-producing sector. The continuing trend of declines in the manufacturing workweek and weakness in Employment Service Jobs does not bode well for our future economic momentum. Retail Sales rose by 1.5 percent in September, its third increase in the past six months. Private Service-Producing Employment growth, which has been weak of late, decelerated in September, yet another potential warning sign moving into next year. Benefit Exhaustions fell by 10.8 percent, a more rapid rate of improvement, so longer-term unemployment remains contained.
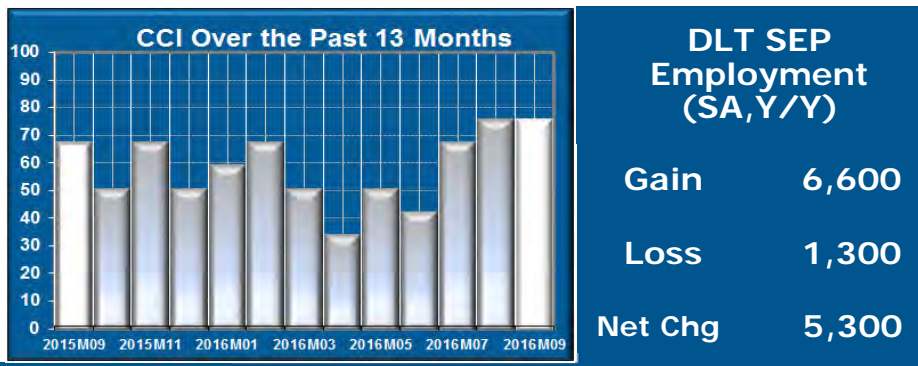

THE BOTTOM LINE

Will Rhode Island's second quarter slide will serve as a wakeup call to our state's elected officials ? Almost ten years after our last employment peak, we remain far too vulnerable to slowing national activity. Worse yet, we also tend to benefit less from national economic growth than do most other states. As asymmetries go, that's about as ugly as it gets! Our fate for the remainder of this year, and into the indefinite future, will continue to be determined almost entirely (and asymmetrically) by national economic momentum. We can only hope the post-election elation ultimately translates into more rapid national (and state) growth.

\begin{tabular}{c|c|c|c|c|c|c|c|c|c|c|c|c|c|} 
& & Jan & Feb & Mar & Apr & May & J un & Jul & Aug & Sep & Oct & Nov & Dec \\
\hline \multirow{2}{*}{2015} & $67 \uparrow$ & $67 \uparrow$ & 67 & $67 \uparrow$ & 67 & $67 \downarrow$ & $58 \downarrow$ & $75 \downarrow$ & $67 \downarrow$ & $50 \downarrow$ & $67 \downarrow$ & $50 \downarrow$ \\
\cline { 2 - 13 } & 2016 & 58 & 67 & $50 \downarrow$ & 42 & 50 & 42 & $67 \uparrow$ & 75 & 75 & & & \\
\hline
\end{tabular}

